\title{
Structural investigations of the two polymorphs of synthetic Fe-cordierite and Raman spectroscopy of hexagonal Fe-cordierite
}

\author{
Udo Haefeker • Reinhard Kaindl • Peter Tropper • \\ Hannes Krüger • Volker Kahlenberg • Maria Orlova
}

Received: 11 June 2013 / Accepted: 25 September 2013 / Published online: 12 October 2013

(C) The Author(s) 2013. This article is published with open access at Springerlink.com

\begin{abstract}
The crystal structures of synthetic hexagonal and orthorhombic Fe-cordierite polymorphs with the space groups $P 6 / \mathrm{mcc}$ and $\mathrm{Cccm}$ were refined from single-crystal $X$-ray diffraction data to $R_{1 \text {, hex }}=3.14 \%$ and $R_{1 \text {, ortho }}=4.48 \%$. The substitution of the larger $\mathrm{Fe}^{2+}$ for $\mathrm{Mg}$ leads to multiple structural changes and an increase of the unit cell volumes, with $a, c$ (hex) $=9.8801(16) \AA, 9.2852(5) \AA$ and $a, b, c$ (ortho)= 17.2306(2) $\AA, 9.8239(1) \AA, 9.2892(1) \AA$ in the end-members. Furthermore $\mathrm{Fe}$ incorporation results in an increase of the volumes of the octahedra, although the diameters of the octahedra in direction of the $c$-axis decrease in both polymorphs. $\mathrm{X}$-ray powder diffraction analysis indicates a high degree of $\mathrm{Al} /$ $\mathrm{Si}$ ordering in the orthorhombic polymorph, the Miyashiro distortion index is $\sim 0.24$. Estimations of site occupancies based on the determined tetrahedral volumes result in the following values for hexagonal $\mathrm{Fe}$-cordierite: $\sim 73 \% \mathrm{Al}$ for $\mathrm{T}_{1}$ and $\sim 28 \%$ Al for $T_{2}$. For the first time Raman spectroscopy was performed on the hexagonal Fe-cordierite polymorph. In the hexagonal Fe-cordierite polymorph most Raman peaks are shifted towards lower wavenumbers when compared with the Mg-end-member.
\end{abstract}

Editorial handling: A. Beran

Electronic supplementary material The online version of this article (doi:10.1007/s00710-013-0313-3) contains supplementary material, which is available to authorized users.

U. Haefeker $(\bowtie) \cdot$ P. Tropper $\cdot$ H. Krüger $\cdot$ V. Kahlenberg $•$ M. Orlova

Institute of Mineralogy and Petrography, University Innsbruck, Innrain 52, 6020 Innsbruck, Austria

e-mail: udo.haefeker@uibk.ac.at

R. Kaindl

MATERIALS - Institute for Surface Technologies and Photonics, Functional Surfaces, JOANNEUM RESEARCH

Forschungsgesellschaft mbH, Leobner Straße 94, 8712 Niklasdorf,

Austria

\section{Introduction}

Cordierite with the simplified formula $\left(\mathrm{Mg}, \mathrm{Fe}_{2} \mathrm{Al}_{4} \mathrm{Si}_{5} \mathrm{O}_{18} * \mathrm{n}\left(\mathrm{H}_{2} \mathrm{O}\right.\right.$, $\mathrm{CO}_{2}$ ) is a framework silicate whose structure consists of corner-sharing $T_{2}$ tetrahedra forming six-membered rings which are crosslinked by additional $\mathrm{T}_{1}$ tetrahedra. Crystal structure and $\mathrm{Al} / \mathrm{Si}$-ordering of $\mathrm{Mg}$-Fe-cordierites were investigated by various authors (e.g., Gibbs 1966; Langer and Schreyer 1969; Meagher and Gibbs 1977; Cohen et al. 1977; Hochella et al. 1979; Putnis 1980; Wallace and Wenk 1980; Armbruster and Bloss 1981; Putnis and Bish 1983; Gunter et al. 1984; Mirwald and Kirchner 1984; Armbruster 1985a, b; Putnis et al. 1985; Putnis et al. 1987; Malcherek et al. 2001; Bertoldi et al. 2004 and references therein; Balassone et al. 2004; Miletich et al. 2010). The tetrahedral positions are occupied by Si and Al. Cordierite occurs in two polymorphs which are distinguished by the $\mathrm{Al} / \mathrm{Si}$ ordering. Most of the natural cordierites adopt the structure of the orthorhombic low-temperature polymorph with space group symmetry $\mathrm{Cccm}$ and a fully ordered $\mathrm{Al} / \mathrm{Si}$ distribution where Al occupies the $T_{1} 1$ and $T_{2} 6$ positions and $\mathrm{Si}$ occupies the $\mathrm{T}_{1} 6, \mathrm{~T}_{2} 1$ and $\mathrm{T}_{2} 3$ tetrahedral sites (e.g., Cohen et al. 1977; Meagher and Gibbs 1977; Hochella et al. 1979). The hexagonal high-temperature polymorph indialite (Miyashiro 1957) with space group symmetry $P 6 / m c c$ shows a disordered $\mathrm{Al} / \mathrm{Si}$ distribution and is isostructural with beryl (e.g., Meagher and Gibbs 1977 and references therein). The $T_{1}$ tetrahedra are preferentially occupied by $\mathrm{Al}$ and the $\mathrm{T}_{2}$ tetrahedra by $\mathrm{Si}$ (e.g., Meagher and Gibbs 1977; Putnis et al. 1985; Putnis and Angel 1985; Winkler et al. 1991). Selected bond distances and angles of the Mg-cordierite polymorphs are given in Table 1. The information provided for hexagonal $\mathrm{Mg}$ cordierite is based on crystallographic data of Winkler et al. (1991). The octahedral M-sites are mainly occupied by $\mathrm{Mg}$ and $\mathrm{Fe}^{2+}$ and $\mathrm{Mg}$-Fe mixing in orthorhombic cordierite is assumed to be ideal (e.g., Boberski and Schreyer 1990). 90 
Table 1 Structural data of both polymorphs of $\mathrm{Mg}$ - and Fe-cordierite
Data based on *Winkler et al. (Winkler et al. 1991) and **Haefeker et al. (2012)

\begin{tabular}{|c|c|c|c|c|}
\hline Cordierite & Mg-hexagonal & Mg-orthorhombic ${ }^{* *}$ & Fe-hexagonal & Fe-orthorhombic \\
\hline \multirow[t]{3}{*}{ Unit Cell $(\AA)$} & $a=9.7683$ & $\mathrm{a}=17.0552(1)$ & $a=9.8801(6)$ & $\mathrm{a}=17.2306(2)$ \\
\hline & & $b=9.7240(1)$ & & $\mathrm{b}=9.8239(1)$ \\
\hline & $\mathrm{c}=9.3408$ & $c=9.3480(1)$ & $\mathrm{c}=9.2852(5)$ & $\mathrm{c}=9.2892(1)$ \\
\hline Cell Volume $\left(\AA^{3}\right)$ & 772 & $1550.323(7)$ & $784.95(8)$ & $1572.40(3)$ \\
\hline$<\mathrm{M}-\mathrm{O}>(\AA)$ & 2.102 & 2.123 & $2.153(2)$ & $2.157(6)$ \\
\hline Octahedral Vol. $\left(\AA^{3}\right)$ & 11.739 & 12.011 & 12.400 & 12.411 \\
\hline$\lambda, \sigma^{2}$ octahedra & $1.037,115.87$ & $1.041,129.66$ & $1.048,147.42$ & $1.051,155.41$ \\
\hline$<\mathrm{T}_{1}-\mathrm{O}>,<\mathrm{T}_{1} 1-\mathrm{O}>(\AA)$ & 1.721 & $1.754(2)$ & $1.715(2)$ & $1.746(7)$ \\
\hline$<\mathrm{T}_{1} 6-\mathrm{O}>(\AA)$ & & $1.624(2)$ & & $1.632(6)$ \\
\hline$<\mathrm{T}_{2}-\mathrm{O}>,<\mathrm{T}_{2} 1-\mathrm{O}>(\AA)$ & 1.648 & $1.609(3)$ & $1.652(2)$ & $1.601(8)$ \\
\hline$<\mathrm{T}_{2} 3-\mathrm{O}>(\AA)$ & & $1.603(3)$ & & $1.634(9)$ \\
\hline$<\mathrm{T}_{2} 6-\mathrm{O}>(\AA)$ & & $1.739(3)$ & & $1.736(8)$ \\
\hline Vol. $T_{1}$, Vol. $T_{1} 1\left(\AA^{3}\right)$ & 2.460 & 2.594 & 2.481 & 2.590 \\
\hline Vol. $\mathrm{T}_{1} 6\left(\AA^{3}\right)$ & & 2.122 & & 2.179 \\
\hline Vol. $T_{2}$, Vol. $T_{2} 1\left(\AA^{3}\right)$ & 2.293 & 2.132 & 2.308 & 2.100 \\
\hline Vol. $T_{2} 3\left(\AA^{3}\right)$ & & 2.110 & & 2.234 \\
\hline Vol. $T_{2} 6\left(\AA^{3}\right)$ & & 2.688 & & 2.671 \\
\hline$\lambda, \sigma^{2}: T_{1}, T_{1} 1$ & $1.042,156.55$ & $1.045,165.20$ & $1.028,109.40$ & $1.036,137.14$ \\
\hline$\lambda, \sigma^{2}: T_{1} 6$ & & $1.023,90.35$ & & $1.016,64.81$ \\
\hline$\lambda, \sigma^{2}: T_{2}, T_{2} 1$ & $1.001,3.85$ & $1.002,7.92$ & $1.001,4.84$ & $1.001,5.95$ \\
\hline$\lambda, \sigma^{2}: T_{2} 3$ & & $1.001,6.030$ & & $1.002,6.52$ \\
\hline$\lambda, \sigma^{2}: T_{2} 6$ & & $1.002,10.75$ & & $1.003,14.16$ \\
\hline
\end{tabular}

to $99 \%$ of the total $\mathrm{Fe}^{2+}$ occupies the octahedral site (Khomenko et al. 2001). The amount of $\mathrm{Fe}^{3+}$ in natural cordierites is insignificant (Geiger et al. 2000). The stacked tetrahedral rings form channels parallel to the crystallographic $c$-axis which can incorporate molecules such as $\mathrm{CO}_{2}$ and $\mathrm{H}_{2} \mathrm{O}$, and also large cations such as $\mathrm{Na}^{+}$or $\mathrm{K}^{+}$. Two channel sites $(\mathrm{Ch} 0$, $\mathrm{Ch}^{1 / 4}$ ) can be distinguished in the structure, according to the general formula: $(\mathrm{M})_{2}\left(\mathrm{~T}_{1} 1\right)_{2}\left(\mathrm{~T}_{2} 6\right)_{2}\left(\mathrm{~T}_{2} 3\right)_{2}\left(\mathrm{~T}_{2} 1\right)_{2}\left(\mathrm{~T}_{1} 6\right) \mathrm{O}_{18}(\mathrm{Ch} 0$, $\mathrm{Ch} 1 / 4)$. Most natural cordierites show $\mathrm{X}_{\mathrm{Fe}}(\mathrm{Fe} / \mathrm{Fe}+\mathrm{Mg}+$ $\mathrm{Mn})<0.9$. Under certain experimental conditions it was possible to synthesize pure Fe-cordierites (e.g., Gunter et al. 1984; Boberski and Schreyer 1990; Kaindl et al. 2011). The incorporation of $\mathrm{Fe}^{2+}$ into the octahedral positions of orthorhombic cordierite then leads to multiple structural changes when compared with $\mathrm{Mg}$-cordierite. The average $\mathrm{M}-\mathrm{O}$ distance increases which leads to an elongation of the crystallographic $a$ and $b$ axis. The average $\mathrm{T}_{1} 1-\mathrm{O}$ distances decrease slightly resulting in a contraction of the $c$-axis (e.g., Wallace and Wenk 1980; Armbruster 1985b; Boberski and Schreyer 1990; Malcherek et al. 2001; Geiger and Grams 2003). All polyhedra in both cordierite polymorphs are distorted. The polyhedral distortion can be quantified with the quadratic elongation $\lambda$ and the angle variance $\sigma^{2}$ (Robinson et al. 1971) and these parameters are also given in Table 1. Several authors investigated cordierite with spectroscopic methods focussing on topics like polymorphism and $\mathrm{Al} / \mathrm{Si}$ ordering (Langer and
Schreyer 1969; McMillan et al. 1984; Güttler et al. 1989; Poon et al. 1990), volatile content (Armbruster and Bloss 1982; Vry et al. 1990; Kalt 2000; Kolesov and Geiger 2000; Yakubovich et al. 2004; Bul'bak and Shvedenkov 2005; Khomenko and Langer 2005; Kaindl et al. 2006; Kolesov 2006; Nasdala et al. 2006; Rigby et al. 2008; Weikusat et al. 2010), structural heterogeneity as well as energetic and structural changes under high pressure (Geiger and Grams 2003; Likhacheva et al. 2011). Group theoretic analysis yields 36 Raman active vibrations for hexagonal Mg-cordierite and 87 for the orthorhombic end-member (e.g. McMillan et al. 1984; Poon et al. 1990; Kaindl et al. 2011). Local structural heterogeneities and thermodynamic mixing properties in natural $\mathrm{Fe}-$ Mg-cordierites have also been studied with IR spectroscopy (Geiger and Grams 2003). The synthetic Fe-end-member has been investigated with X-ray powder diffraction and IR spectroscopic methods (Gunter et al. 1984; Boberski and Schreyer 1990) but not using Raman spectroscopy so far. Quantummechanical calculations of Raman spectra of ordered $\mathrm{Mg}$ - and $\mathrm{Fe}$-cordierites yielded a detailed peak assignment and a theoretical description of the effects of the $\mathrm{Mg}$-Fe exchange and $\mathrm{Al} /$ Si ordering (Kaindl et al. 2011). The effect of Fe incorporation on six selected Raman bands of synthetic hydrous orthorhombic cordierite has been investigated by Haefeker et al. (2012). The aim of this work is to provide detailed structural data for both polymorphs of synthetic Fe-cordierite and for the first 
time Raman spectroscopic data for the hexagonal polymorph. A thorough literature search showed that appropriate crystallographic data of both polymorphs and Raman spectra of synthetic hexagonal Fe-cordierite are not available in the literature yet. The investigations described in this contribution include comprehensive structural refinements based on X-ray single-crystal and powder diffraction, as well as descriptions of single bands and peaks of hexagonal cordierite Raman spectra. A method based on the comparison of tetrahedral volumes was applied to obtain information about the $\mathrm{Al} / \mathrm{Si}$ ordering in hexagonal Fe-cordierite.

\section{Experimental methods}

Synthesis of Fe-cordierite

Disordered hexagonal and ordered orthorhombic Fecordierites were synthesized from stoichiometric glass using annealing and hydrothermal techniques. The detailed description can be found in Kaindl et al. (2011).

An oxide mixture with the stoichiometry $\mathrm{Fe}_{2.3} \mathrm{Al}_{4} \mathrm{Si}_{5} \mathrm{O}_{18}$ was molten in reducing atmosphere and then quenched in distilled water. Apart from elementary iron, which could be found as sparsely scattered small spheres, the glass was homogenous and showed the composition $\mathrm{Fe}_{2} \mathrm{Al}_{4} \mathrm{Si}_{5} \mathrm{O}_{18}$. Tempering the glass at $900{ }^{\circ} \mathrm{C}$ for $21 \mathrm{~h}$ together with graphite-powder in a sealed gold capsule lead to the crystallization of disordered hexagonal cordierite. A higher degree of $\mathrm{Si}$-Al-ordering in the orthorhombic end-product was achieved by additional hydrothermal treatment for 2 weeks at $700{ }^{\circ} \mathrm{C}$ and 2 kbar.

\section{Raman spectroscopy}

Raman spectroscopic investigations were performed using a Labram HR-800 confocal Raman-spectrometer by HORIBA under ambient conditions and in a Linkam THMS 600 cooling stage at $-190^{\circ} \mathrm{C}$. A $100 \mathrm{x}$ objective with a numerical aperture of 0.9 was used for the measurements under ambient conditions and a 50x objective with a numerical aperture of 0.5 was used in combination with the cooling stage. Unpolarized spectra of randomly oriented hexagonal Fe-cordierite crystal aggregates were recorded using the $532 \mathrm{~nm}$ excitation wavelength of a $30 \mathrm{~mW} \mathrm{Nd-YAG} \mathrm{laser} \mathrm{as} \mathrm{well} \mathrm{as} \mathrm{the} 633 \mathrm{~nm}$ line of a $17 \mathrm{~mW}$ He-Ne-laser. Small crystal sizes and/or twinning hampered single-crystal measurements. The spectra were recorded in the range of $100-1,250 \mathrm{~cm}^{-1}$. During all measurements the confocal pinhole aperture was $1,000 \mu \mathrm{m}$ and the width of the entrance slit was $100 \mu \mathrm{m}$. A grating with 1,800 lines/mm was used to disperse the scattered Raman light and an open-electrode charge-coupled device with $1,024 \times 256$ pixels, each with a size of $43 \mu \mathrm{m}$, was used for detection.
The spectral resolution of $1.4 \mathrm{~cm}^{-1}$ (green) and $0.9 \mathrm{~cm}^{-1}$ (red) was determined by measuring the Rayleigh line. To obtain high accuracy, the system was calibrated with emission lines of a $\mathrm{Ne}$ spectral calibration lamp and the resulting deviation was $\pm 0.24 \mathrm{~cm}^{-1}$. The spectral software suite LabSPEC 5 (Horiba 2005) was used to fit the Raman spectra and the line-segments baseline correction and convoluted GaussLorentz functions were used for peak fitting.

\section{X-ray powder diffraction}

A Bruker D8 Discover system with a Bragg-Brentanogeometry was used for powder X-ray investigations of the orthorhombic Fe-cordierite. The system was equipped with a silicon-strip-detector and a primary beam Qz(101)-monochromator. The sample was scanned over a $2 \Theta$ range from $5^{\circ}$ to $80.25^{\circ}$ in steps of $0.009^{\circ}$. The Mg-cordierite sample was investigated with a Stoe STADI-MP diffractometer system in bisecting transmission geometry. The system was equipped with a "Mythen" $1 \mathrm{k}$ detector and an asymmetric primary beam $\mathrm{Ge}(111)$-monochromator. Data were collected in a $2 \Theta$ range from 2 to $129.8^{\circ}$ in steps of $0.009^{\circ}$. For LeBail fits and Rietveld calculations the program FullProf.2 k (RodriguezCarvajal 2011) was used.

Vestiges of hexagonal intermediates in the powder sample significantly complicated Rietveld refinements of orthorhombic Fe-cordierite data. LeBail fits (with $R_{\mathrm{p}}=1.94 \%, R_{\mathrm{wp}}=2.69 \%$, $\chi^{2}=3.24$ ) yielded the lattice parameters given in Table 1 and the distortion index (Miyashiro 1957) of $\Delta \approx 0.24$. Rietveld refinements of the orthorhombic Mg-cordierite data (with $R_{\mathrm{b}}$ $\left.=3.47 \%, R_{\mathrm{f}}=2.79 \%, R_{\mathrm{p}}=4.65 \%, R_{\mathrm{wp}}=6.10 \%, \chi^{2}=2.58\right)$ yielded the structural information given in Table 1 with a distortion index $\Delta \approx 0.24$. The background was determined by linear interpolation between a set of breakpoints with refineable heights. Intensities within 10-times the full-width at halfmaximum of a peak were considered to contribute to the central reflection. Thompson-Cox-Hastings pseudo-Voigt functions were chosen for the simulation of the peak shape, including an asymmetry correction following Finger et al. (1994).

\section{Single-crystal X-ray diffraction}

The disordered hexagonal and the ordered orthorhombic Fecordierite samples were measured at ambient conditions with a Stoe IPDS II single-crystal diffractometer using graphite monochromatized Mo-K $\alpha$ radiation. After integration, data reduction included Lorentz and polarization corrections. Furthermore, an analytical absorption correction based on a description of the morphology by accurately indexed and measured external faces was applied. The structures were solved using the program Superflip (Palatinus and Chapuis 2007) and subsequently refined using Jana 2006 (Petricek et al. 2006). Neutral atom scattering coefficients and anomalous dispersion 
corrections were taken from the International Tables for Crystallography, Volume C (Wilson 1995). The parameters for X-ray data collection and structure refinement are given in Table 2. Orthorhombic Fe-cordierite shows pseudo-hexagonal micro-scale twinning and twinnig in synthetic orthorhombic Mg-cordierite has been described in literature (e.g., Putnis 1980; Armbruster 1985a; Blackburn and Salje 1999). The refinement of the orthorhombic Fe-cordierite was performed assuming three twin-domains, related to each other by a $60^{\circ}$ rotation around $c$. One of the three twin individuals dominates the diffraction pattern with a volume fraction of $47 \%$. As a result, the symmetry of the diffraction pattern is clearly reduced to orthorhombic and up to the largest diffracting angle of $29.3^{\circ}$

Table 2 Parameters from single-crystal X-ray data collection and structure refinement of Fe-cordierite

\begin{tabular}{|c|c|c|}
\hline Crystal data for & $\begin{array}{l}\text { Hexagonal } \\
\text { Fe-cordierite }\end{array}$ & $\begin{array}{l}\text { Orthorhombic } \\
\text { Fe-cordierite }\end{array}$ \\
\hline \multirow[t]{3}{*}{ Cell dimensions $(\AA)$} & $a=9.8801(6)$ & $a=17.2306(2)$ \\
\hline & & $b=9.8239(1)$ \\
\hline & $c=9.2852(5)$ & $c=9.2892(1)$ \\
\hline Cell volume $\left(\AA^{3}\right)$ & $784.95(8)$ & $1572.40(3)$ \\
\hline Space group & $P 6 / m c c$ & $\mathrm{Cccm}$ \\
\hline Z & 2 & 4 \\
\hline Chemical formula & $\mathrm{Fe}_{2} \mathrm{Al}_{4} \mathrm{Si}_{5} \mathrm{O}_{18}$ & $\mathrm{Fe}_{2} \mathrm{Al}_{4} \mathrm{Si}_{5} \mathrm{O}_{18}$ \\
\hline Diffractometer type & STOE IPDS II & STOE IPDS II \\
\hline $\mathrm{X}$-ray radiation & Mo- $K \propto(0.71073)$ & Mo- $K \propto(0.71073)$ \\
\hline $\mathrm{X}$-ray power $(\mathrm{kV}, \mathrm{mA})$ & 50,40 & 50,40 \\
\hline Temperature $(\mathrm{K})$ & 298 & 298 \\
\hline Crystal size (mm) & $0.2 \times 0.12 \times 0.06$ & $0.18 \times 0.12 \times 0.08$ \\
\hline $\begin{array}{l}\text { Absorption correction } \\
\text { Integration }\end{array}$ & STOE $X$-RED32 1.31 & STOE $X$-RED32 1.31 \\
\hline $\begin{array}{l}\text { Transmission factors } T \\
\min / T \max \end{array}$ & $0.658 / 0.853$ & $0.767 / 0.850$ \\
\hline Time per frame (s) & 60 & 60 \\
\hline Number of frames & 180 & 360 \\
\hline Reflections collected & 6698 & 7043 \\
\hline $\operatorname{Max} . \theta\left(^{\circ}\right)$ & 29.07 & 29.31 \\
\hline \multirow[t]{3}{*}{ Index range } & $-12 \leq h \leq 13$ & $-23 \leq h \leq 23$ \\
\hline & $-12 \leq k \leq 11$ & $-13 \leq k \leq 13$ \\
\hline & $-12 \leq l \leq 12$ & $-12 \leq l \leq 12$ \\
\hline Unique reflections & 384 & 1123 \\
\hline Reflections $>3 \sigma(\mathrm{I})$ & 370 & 1052 \\
\hline Number of parameters & 27 & 79 \\
\hline$R$ int & 0.035 & 0.057 \\
\hline GooF (S) & 3.66 & 2.89 \\
\hline Weighting scheme & $\mathrm{w}=1 / \sigma^{2}(F)+(0.01 F)^{2}$ & $\mathrm{w}=1 / \sigma^{2}(F)+(0.01 F)^{2}$ \\
\hline$R 1\left[F^{2}>2 \sigma\left(F^{2}\right)\right]$ & 0.0314 & 0.0448 \\
\hline $\mathrm{w} R\left(F^{2}\right)$ & 0.0457 & 0.0478 \\
\hline$\Delta \rho \min \left(\mathrm{e} \AA^{-3}\right)$ & -0.63 & -0.8 \\
\hline$\Delta \rho \max \left(\mathrm{e} \AA^{-3}\right)$ & 0.77 & 1.67 \\
\hline
\end{tabular}

$(\Theta)$, no obvious splitting of the reflections could be observed. Using averaged reflection positions of the three pseudohexagonal twin domains for refinement of the lattice parameters forces the resulting cell to be of almost perfect hexagonal metric $(a=17.1538(11) b=9.8689(6)): \arctan (a / b)=60.09^{\circ}$. The corresponding angle is $60.31^{\circ}$ if the cell parameters determined from powder data are used. Unless the reflections of the twin-related domains can be resolved, 'single-crystal lattice parameters' will underestimate the orthorhombic distortion of the unit cell. As a consequence, we decided to use 'powder lattice parameters' (see section X-ray powder diffraction) for final geometry calculations. Residual electron density determined by difference Fourier-maps is related to $\mathrm{H}_{2} \mathrm{O} / \mathrm{Na}^{+}$contents in the channels. The VESTA 3 software (Momma and Izumi 2011) was used to visualize crystal structures and structural details as bond length, angles, polyhedral volumes and distortion parameters.

Electron microprobe analysis

A JEOL JXA 8100 SUPERPROBE at the Institute of Mineralogy and Petrography at the University of Innsbruck was used for chemical analysis of the synthesis products. The Fe-cordierite single-crystal used for structural investigations was embedded randomly oriented in an epoxy mount, ground and finally polished using a $1 \mu \mathrm{m}$ diamond suspension. Analytical conditions for the wavelength dispersive measurements were $15 \mathrm{kV}$ acceleration voltage, a beam current of $10 \mathrm{nA}$, and counting times of $20 \mathrm{~s}$ for the peak and $10 \mathrm{~s}$ for the background. Calibration was done using the following microprobe standards (standardized element in parenthesis): jadeite $(\mathrm{Na})$, corundum (Al), almandine (Fe) and orthoclase ( $\mathrm{Si}$ ). The analysis yielded the following composition (wt.- $\%$, the numbers in parentheses are $2 \sigma$ standard deviations): $\mathrm{FeO}=21.12(30), \mathrm{SiO}_{2}=44.72(32)$, $\mathrm{Al}_{2} \mathrm{O}_{3}=31.06(26), \mathrm{Na}_{2} \mathrm{O}=0.16(4), \sum$ 97.06. The average mineral formula was then calculated on the anhydrous basis of 18 oxygens, to be $\mathrm{Fe}_{1.96} \mathrm{Al}_{4.064} \mathrm{Si}_{4.963} \mathrm{O}_{18}, \mathrm{Na}_{0.035}$. An exact quantification of the channel- $\mathrm{H}_{2} \mathrm{O}$ is missing and the estimated amount is $1.5-2 w t .-\%$.

\section{Results}

Crystal structure and Raman spectra of $\mathrm{Fe}^{2+}$-cordierites

The atomic coordinates and equiv. displacement parameters of hexagonal Fe-cordierite are presented in Table 3. Anisotropic displacement parameters can be found in the attached cif-files that have been deposited as Supplementary material. Information about the unit cell (lattice parameters, volume) and single polyhedra (average distances, volumes, distortion parameters) is given in Table 1. Selected distances and angles 
Table 3 Fractional atomic coordinates and equivalent displacement parameters of hexagonal $\mathrm{Fe}$-cordierite at RT

\begin{tabular}{lllll}
\hline Atom & $\mathrm{x}$ & $\mathrm{y}$ & $\mathrm{z}$ & $U(\mathrm{eq})$ \\
\hline $\mathrm{Fe}$ & $2 / 3$ & $1 / 3$ & $1 / 4$ & $0.0164(3)$ \\
$\mathrm{T}_{1}$ & $1 / 2$ & $1 / 2$ & $1 / 4$ & $0.0143(4)$ \\
$\mathrm{T}_{2}$ & $0.36842(12)$ & $0.10347(11)$ & 0 & $0.0155(4)$ \\
$\mathrm{O}_{1}$ & $0.4805(2)$ & $0.1319(2)$ & $0.14485(18)$ & $0.0199(7)$ \\
$\mathrm{O}_{2}$ & $0.2277(4)$ & $-0.0782(3)$ & 0 & $0.0295(12)$ \\
\hline
\end{tabular}

$\mathrm{U}(\mathrm{eq})$ is defined as one third of the trace of the orthogonalized $\mathrm{U}_{\mathrm{ij}}$ tensor

(T-O, M-O, O-O) are presented in Table 4. The crystal structure is shown in Fig. 1.

The Raman spectra of synthetic hexagonal Fe-cordierite at ambient conditions and at $-190{ }^{\circ} \mathrm{C}$ are shown in Figs. 2a-c and the Raman band positions taken from Fig. $2 \mathrm{a}(532 \mathrm{~nm})$ are given in Table 5. The most intensive peak occurs at $568 \mathrm{~cm}^{-1}$. Characteristic for the low-frequency region of the spectrum are a low-intensity peak at $372 \mathrm{~cm}^{-1}$ and sharp low- to medium-intensity peaks at 111 and $257 \mathrm{~cm}^{-1}$. The latter overlaps with low-intensity peaks at 238, 272 and $297 \mathrm{~cm}^{-1}$. A broad band system contains three low-intensity peaks at 437,458 and $482 \mathrm{~cm}^{-1}$. The high-frequency region is characterised by low-intensity peaks at 661 and $724 \mathrm{~cm}^{-1}$. Two low-intensity band systems containing overlapping broad peaks occur at 1) $908,968,1,019$ and $1,051 \mathrm{~cm}^{-1}$ and 2) 1 , $105,1,139$ and $1,177 \mathrm{~cm}^{-1}$. Variations of peak intensities in Fig. $2 \mathrm{a}(532 \mathrm{~nm})$ and Fig. $2 \mathrm{~b}(633 \mathrm{~nm})$ are the result of crystal orientation.

The atomic coordinates and equivalent displacement parameters of orthorhombic Fe-cordierite are listed in Table 6. Information about the unit cell (lattice parameters, volume) and polyhedra (average distances, volumes, distortion parameters)

Table 4 Selected bond-distances and angles of hexagonal Fe-cordierite

\begin{tabular}{lllll}
\hline $\mathrm{T}, \mathrm{M}-\mathrm{O}$ distances $(\AA)$ & \multicolumn{2}{l}{$\mathrm{O}-\mathrm{O}$ distances $(\AA)$} & $\mathrm{O}-\mathrm{T}-\mathrm{O}$ angles $\left(^{\circ}\right)$ \\
\hline $\mathrm{T}_{1}-\mathrm{O}_{1}$ & $1.714(2)[\times 4]$ & $\mathrm{O}_{1}-\mathrm{O}_{1}$ & $2.819(3)[\times 2]$ & $110.58(11)$ \\
& & $\mathrm{O}_{1}-\mathrm{O}_{1}$ & $2.581(3)[\times 2]$ & $97.67(11)$ \\
& & $\mathrm{O}_{1}-\mathrm{O}_{1}$ & $2.985(3)[\times 2]$ & $121.00(10)$ \\
& & $\mathrm{Mean}$ & 2.795 & 109.75 \\
$\mathrm{~T}_{2}-\mathrm{O}_{1}$ & $1.674(2)[\times 2]$ & $\mathrm{O}_{1}-\mathrm{O}_{2}$ & $2.704(3)[\times 2]$ & $110.01(9)$ \\
$\mathrm{T}_{2}-\mathrm{O}_{2}$ & $1.631(2)[\times 1]$ & $\mathrm{O}_{1}-\mathrm{O}_{2}$ & $2.678(3)[\times 2]$ & $108.25(11)$ \\
$\mathrm{T}_{2}-\mathrm{O}_{2}$ & $1.627(4)[\times 1]$ & $\mathrm{O}_{2}-\mathrm{O}_{2}$ & $2.720(5)[\times 1]$ & $113.2(3)$ \\
& & $\mathrm{O}_{1}-\mathrm{O}_{1}$ & $2.690(3)[\times 1]$ & $106.90(15)$ \\
$\mathrm{Mean}$ & 1.652 & $\mathrm{Mean}_{2}$ & 2.696 & 109.44 \\
$\mathrm{Fe}-\mathrm{O}_{1}$ & $2.153(3)[\times 6]$ & $\mathrm{O}_{1}-\mathrm{O}_{1}$ & $2.581(3)[\times 3]$ & $73.66(9)$ \\
& & $\mathrm{O}_{1}-\mathrm{O}_{1}$ & $2.898(3)[\times 3]$ & $84.58(8)$ \\
& & $\mathrm{O}_{1}-\mathrm{O}_{1}$ & $3.324(3)[\times 6]$ & $101.05(9)$ \\
& & $\mathrm{Mean}$ & 3.032 & 90.09 \\
\hline
\end{tabular}

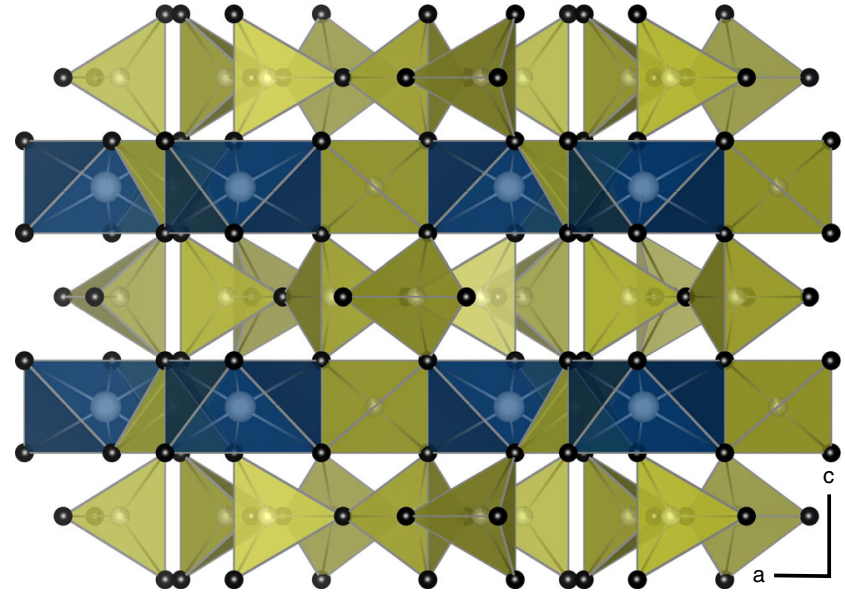

Fig. 1 The crystal structure of hexagonal Fe-cordierite at room temperature shown along the $b$-axis. The Fe-bearing octahedra are shown in dark blue, the $\mathrm{Si} / \mathrm{Al}$ tetrahedra in chartreuse

is given in Table 1. Selected distances and angles (T-O, M-O, O-O) are summarized in Table 7. The crystal structure is shown in Fig. 3.

\section{$\mathrm{Al}$, Si distribution}

Calculations based on the comparison between the tetrahedral volumes in ordered and disordered cordierites can be used to estimate the $\mathrm{Al} / \mathrm{Si}$ distribution in hexagonal cordierite. The comparison of the five tetrahedral volumes of the fullyordered naturally occurring Mg-rich Whitewell-cordierite (Cohen et al. 1977) and a highly ordered pure synthetic Mgcordierite (Kaindl et al. 2011; Haefeker et al. 2012) show only small deviations of $0.8-2.2 \%$. Based upon site occupancies and their position within the cordierite's framework five individual tetrahedral volumes in the ordered orthorhombic $\left(T_{1} 1\right.$, $\left.\mathrm{T}_{1} 6, \mathrm{~T}_{2} 1, \mathrm{~T}_{2} 3, \mathrm{~T}_{2} 6\right)$ and two in the disordered hexagonal cordierites $\left(\mathrm{T}_{1}, \mathrm{~T}_{2}\right)$ can be distinguished. In orthorhombic Fecordierite (Table 1), the volume of $\mathrm{T}_{1} 6_{(\mathrm{Si})}$ with $2.179 \AA^{3}$ represents $0 \% \mathrm{Al}$ occupation and the volume of $\mathrm{T}_{1} 1_{(\mathrm{Al})}$ with $2.590 \AA^{3}$ represents $100 \% \mathrm{Al}$ occupation, leading to the following linear equation to estimate the $\mathrm{Al} / \mathrm{Si}$ distribution in the 'mixed' $\mathrm{T}_{1}$ tetrahedra:

Occ. $-\%_{A l}=242.95 \cdot \mathrm{Vol}_{T 1}-529.32$.

In hexagonal Fe-cordierite the $\mathrm{T}_{1}$ volume of $2.481 \AA^{3}$ (Table 1 ) is occupied by $\sim 73 \% \mathrm{Al}$. The equation for $\mathrm{T}_{2}$

Occ. $-\%_{A l}=198.26 \cdot \mathrm{Vol}_{T 2}-429.62$

is based on the average orthorhombic $\mathrm{T}_{2} 1_{(\mathrm{Si})} / \mathrm{T}_{2} 3_{(\mathrm{Si})}$ volume of $2.167 \AA^{3}$ and the $\mathrm{T}_{2} \mathrm{G}_{(\mathrm{Al})}$ volume of $2.671 \AA^{3}$. The $\mathrm{T}_{2}$-volume of $2.308 \AA^{3}$ in hexagonal Fe-cordierite (Table 1) corresponded to an occupancy of $\sim 28 \% \mathrm{Al}$. Expressed in atoms per formula 
Fig. 2 (a-c) Raman spectra of two randomly oriented hexagonal Fe-cordierites. Sample 1 was recorded with $532 \mathrm{~nm}$ under ambient conditions (a) and sample 2 was recorded with $633 \mathrm{~nm}$ under ambient conditions (b) and at $-190{ }^{\circ} \mathrm{C}$ (c)

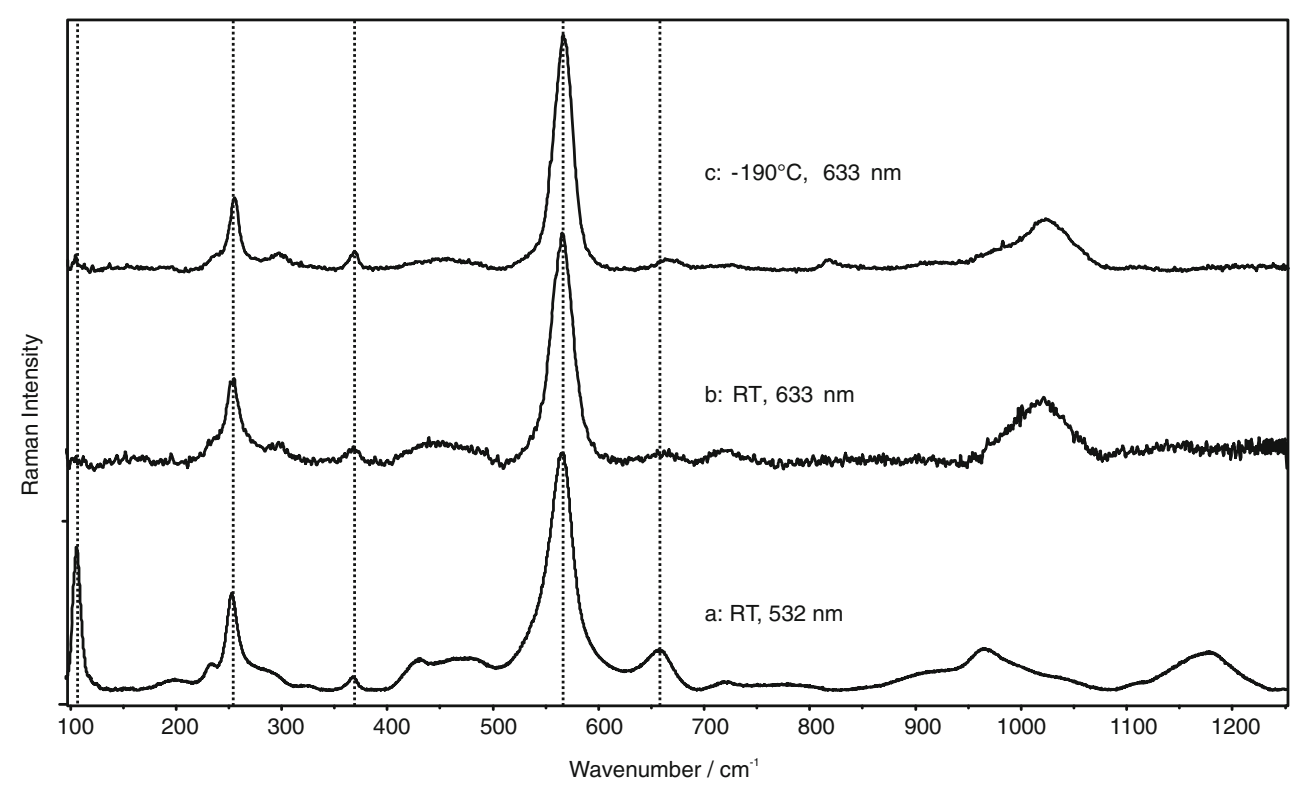

unit (a.p.f.u.) this amounts to $2.2 \mathrm{Al}$ and $0.8 \mathrm{Si}$ a.p.f.u. for $\mathrm{T}_{1}$ and 1.7 $\mathrm{Al}$ and 4.3 Si a.p.f.u. for $\mathrm{T}_{2}\left(\sum=3.9 \mathrm{Al}\right.$ and 5.1 Si).

For hexagonal $\mathrm{Mg}$-cordierite (Table 1) the equations

Occ. $-\% o_{A l}=215.8 \cdot \operatorname{Vol}_{T 1}-463.85$

and

Occ. $-\%$ Al $=179.9 \cdot \operatorname{Vol}_{T 2}-380.56$

were developed similarly thus yielding $\sim 67 \% \mathrm{Al}$ in $\mathrm{T}_{1}$ and $\sim 32 \% \mathrm{Al}$ in $\mathrm{T}_{2}$ tetrahedra, this amounts to $2.0 \mathrm{Al}$ and $1.0 \mathrm{Si}$ a.p.f.u. for $\mathrm{T}_{1}$ and $1.9 \mathrm{Al}$ and $4.1 \mathrm{Si}$ a.p.f.u. for $\mathrm{T}_{2}$ $\left(\sum=3.9 \mathrm{Al}\right.$ and $\left.5.1 \mathrm{Si}\right)$. Tetrahedral volumes were calculated based on the structural data of a synthetic orthorhombic Mgcordierite from Haefeker et al. (2012) and data for hexagonal Mg-cordierite of Winkler et al. (1991).

Table 5 Raman peak positions of hexagonal Fe-cordierite

\begin{tabular}{llll}
\hline Low-freq. region $\left(\mathrm{cm}^{-1}\right)$ & \multicolumn{2}{l}{ High-freq. region $\left(\mathrm{cm}^{-1}\right)$} \\
\hline 111 & $\mathrm{~m}$ & 568 & $\mathrm{~h}$ \\
203 & 1 & 661 & 1 \\
238 & 1 & 724 & 1 \\
257 & $\mathrm{~m}$ & 773 & 1 \\
272 & 1 & 908 & 1 \\
297 & 1 & 968 & 1 \\
328 & 1 & 1019 & 1 \\
372 & 1 & 1051 & 1 \\
437 & 1 & 1105 & 1 \\
458 & 1 & 1139 & 1 \\
482 & 1 & 1177 & 1 \\
\hline
\end{tabular}

$l$ low, $m$ medium, $h$ high (Raman intensity)

\section{Discussion}

Determination of the octahedral diameter in Mg-Cordierite

The diameter of the octahedra in direction of the $c$-axis can be used as useful indicator to explain structural changes in cordierite and has to be determined differently for both polymorphs. The octahedra of the hexagonal Mg-cordierite show two parallel faces perpendicular to the $c$-axis with a facecenter-face distance of $1.982 \AA$. In the orthorhombic polymorph these octahedra faces are tilted and the face-center-face distances have to be averaged to obtain comparable data. Both octahedral faces are defined by three oxygen atoms with different fractional z coordinates. Constructing (001) planes

Table 6 Fractional atomic coordinates and equivalent displacement parameters of orthorhombic Fe-cordierite at RT

\begin{tabular}{lllll}
\hline Atom & $\mathrm{x}$ & $\mathrm{y}$ & $\mathrm{z}$ & $U(\mathrm{eq})$ \\
\hline $\mathrm{Fe}$ & $0.16316(11)$ & $1 / 2$ & $1 / 4$ & $0.0135(4)$ \\
$\mathrm{T}_{1} 1(\mathrm{Al})$ & $3 / 4$ & $3 / 4$ & $0.2497(5)$ & $0.0119(9)$ \\
$\mathrm{T}_{1} 6(\mathrm{Si})$ & 0 & $1 / 2$ & $1 / 4$ & $0.0130(13)$ \\
$\mathrm{T}_{2} 1(\mathrm{Si})$ & $0.69041(18)$ & $0.5781(3)$ & $1 / 2$ & $0.0123(8)$ \\
$\mathrm{T}_{2} 3(\mathrm{Si})$ & $0.63450(19)$ & $0.7350(3)$ & 0 & $0.0111(8)$ \\
$\mathrm{T}_{2} 6(\mathrm{Al})$ & $0.0488(2)$ & $0.6934(3)$ & 0 & $0.0107(8)$ \\
$\mathrm{O}_{1} 1$ & $0.7443(3)$ & $0.6050(6)$ & $0.3597(6)$ & $0.0149(15)$ \\
$\mathrm{O}_{1} 6$ & $0.0611(3)$ & $0.5866(5)$ & $0.1518(6)$ & $0.0130(14)$ \\
$\mathrm{O}_{1} 3$ & $0.6734(3)$ & $0.8056(6)$ & $0.1434(7)$ & $0.0180(18)$ \\
$\mathrm{O}_{2} 6$ & $0.5423(5)$ & $0.7476(7)$ & 0 & $0.0146(19)$ \\
$\mathrm{O}_{2} 1$ & $0.6221(5)$ & $0.6865(9)$ & 0 & $0.024(3)$ \\
$\mathrm{O}_{2} 3$ & $0.6621(4)$ & $0.5739(9)$ & 0 & $0.017(2)$ \\
\hline
\end{tabular}

$\mathrm{U}(\mathrm{eq})$ is defined as one third of the trace of the orthogonalized Uij tensor 
Table 7 Selected bond-distances and angles of orthorhombic Fecordierite

\begin{tabular}{|c|c|c|c|c|}
\hline \multicolumn{2}{|c|}{ T, M-O distances $(\AA)$} & \multicolumn{2}{|c|}{ O-O distances $(\AA)$} & \multirow{2}{*}{$\frac{\text { O-T-O angles }\left({ }^{\circ}\right)}{122.9(3)}$} \\
\hline $\mathrm{T}_{1} 1-\mathrm{O}_{1} 3$ & $1.736(7)[\times 2]$ & $\mathrm{O}_{1} 1-\mathrm{O}_{1} 3$ & $3.068(9)[\times 2]$ & \\
\hline \multirow[t]{3}{*}{$\mathrm{T}_{1} 1-\mathrm{O}_{1} 1$} & $1.756(7)[\times 2]$ & $\mathrm{O}_{1} 3-\mathrm{O}_{1} 3$ & $2.857(8)$ & $110.7(3)$ \\
\hline & & $\mathrm{O}_{1} 3-\mathrm{O}_{1} 1$ & $2.611(9)[\times 2]$ & $96.8(3)$ \\
\hline & & $\mathrm{O}_{1} 1-\mathrm{O}_{1} 1$ & $2.856(9)$ & $108.8(3)$ \\
\hline Mean & $1.746(7)$ & Mean & $2.845(9)$ & 109.82 \\
\hline \multirow[t]{4}{*}{$\mathrm{T}_{1} 6-\mathrm{O}_{1} 6$} & $1.632(6)[\times 4]$ & $\mathrm{O}_{1} 6-\mathrm{O}_{1} 6$ & $2.495(8)[\times 2]$ & $99.7(2)$ \\
\hline & & $\mathrm{O}_{1} 6-\mathrm{O}_{1} 6$ & $2.786(8)[\times 2]$ & $117.2(2)$ \\
\hline & & $\mathrm{O}_{1} 6-\mathrm{O}_{1} 6$ & $2.707(8)[\times 2]$ & $112.0(2)$ \\
\hline & & Mean & $2.663(8)$ & 109.63 \\
\hline $\mathrm{T}_{2} 1-\mathrm{O}_{1} 1$ & $1.622(6)[\times 2]$ & $\mathrm{O}_{2} 3-\mathrm{O}_{1} 1$ & $2.606(10)[\times 2]$ & 109.43(19) \\
\hline $\mathrm{T}_{2} 1-\mathrm{O}_{2} 1$ & $1.587(10)$ & $\mathrm{O}_{2} 3-\mathrm{O}_{2} 1$ & $2.649(13)$ & $114.0(4)$ \\
\hline \multirow[t]{2}{*}{$\mathrm{T}_{2} 1-\mathrm{O}_{2} 3$} & $1.571(10)$ & $\mathrm{O}_{2} 1-\mathrm{O}_{1} 1$ & $2.603(10)[\times 2]$ & $108.37(17)$ \\
\hline & & $\mathrm{O}_{1} 1-\mathrm{O}_{1} 1$ & $2.607(8)$ & $106.9(3)$ \\
\hline Mean & $1.601(8)$ & Mean & $2.612(10)$ & 109.4 \\
\hline $\mathrm{T}_{2} 3-\mathrm{O}_{1} 3$ & $1.645(7)[\times 2]$ & $\mathrm{O}_{2} 3-\mathrm{O}_{2} 6$ & $2.678(12)$ & $111.2(3)$ \\
\hline $\mathrm{T}_{2} 3-\mathrm{O}_{2} 6$ & $1.593(10)$ & $\mathrm{O}_{2} 3-\mathrm{O}_{1} 3$ & $2.645(10)[\times 2]$ & $106.7(3)$ \\
\hline \multirow[t]{2}{*}{$\mathrm{T}_{2} 3-\mathrm{O}_{2} 3$} & $1.653(10)$ & $\mathrm{O}_{2} 6-\mathrm{O}_{1} 3$ & $2.684(10)[\times 2]$ & $111.94(18)$ \\
\hline & & $\mathrm{O}_{1} 3-\mathrm{O}_{1} 3$ & $2.664(10)$ & $108.2(3)$ \\
\hline Mean & $1.634(9)$ & Mean & $2.667(10)$ & 109.45 \\
\hline $\mathrm{T}_{2} 6-\mathrm{O}_{1} 6$ & $1.770(6)[\times 2]$ & $\mathrm{O}_{2} 1-\mathrm{O}_{1} 6$ & $2.839(10)[\times 2]$ & $108.5(2)$ \\
\hline $\mathrm{T}_{2} 6-\mathrm{O}_{2} 1$ & $1.728(10)$ & $\mathrm{O}_{2} 1-\mathrm{O}_{2} 6$ & $2.896(13)$ & $116.68(18)$ \\
\hline \multirow[t]{2}{*}{$\mathrm{T}_{2} 6-\mathrm{O}_{2} 6$} & $1.673(10)$ & $\mathrm{O}_{2} 6-\mathrm{O}_{1} 6$ & $2.796(9)[\times 2]$ & $108.5(3)$ \\
\hline & & $\mathrm{O}_{1} 6-\mathrm{O}_{1} 6$ & $2.820(8)$ & $105.60(19)$ \\
\hline Mean & $1.736(8)$ & Mean & $2.831(10)$ & 109.38 \\
\hline $\mathrm{M}-\mathrm{O}_{1} 1$ & $2.155(6)[\times 2]$ & $\mathrm{O}_{1} 1-\mathrm{O}_{1} 6$ & $3.360(8)[\times 2]$ & $\mathrm{O}-\mathrm{M}-\mathrm{O}$ angles $\left({ }^{\circ}\right)$ \\
\hline $\mathrm{M}-\mathrm{O}_{1} 3$ & $2.158(7)[\times 2]$ & $\mathrm{O}_{1} 6-\mathrm{O}_{1} 6$ & $2.495(8)$ & $70.70(18)$ \\
\hline $\mathrm{M}-\mathrm{O}_{1} 6$ & $2.156(6)[\times 2]$ & $\mathrm{O}_{1} 1-\mathrm{O}_{1} 1$ & $2.900(9)$ & $74.51(16)$ \\
\hline \multirow[t]{5}{*}{ Mean } & $2.157(6)$ & $\mathrm{O}_{1} 3-\mathrm{O}_{1} 1$ & $2.611(9)[\times 2]$ & $84.56(19)$ \\
\hline & & $\mathrm{O}_{1} 3-\mathrm{O}_{1} 1$ & $3.265(9)[\times 2]$ & $84.93(16)$ \\
\hline & & $\mathrm{O}_{1} 3-\mathrm{O}_{1} 6$ & $2.913(8)[\times 2]$ & $98.40(17)$ \\
\hline & & $\mathrm{O}_{1} 3-\mathrm{O}_{1} 6$ & $3.372(8)[\times 2]$ & $102.39(15)$ \\
\hline & & Mean & $3.036(8)$ & $102.81(17)$ \\
\hline
\end{tabular}

perpendicular to the $c$-axis, each passing through one of the related oxygens, yields the three different $\mathrm{O}_{\text {Plane }}-{ }^{-c e n t e r-} \mathrm{O}_{\text {Plane }}$ distances of namely $2.049 \AA, 2.047 \AA$ and $1.872 \AA$. Their average leads to an octahedral diameter in direction of the $c$ axis of $1.989 \AA$. The octahedral diameters of Fe-cordierite are discussed below.

\section{Hexagonal Fe-cordierite}

$\mathrm{Fe}^{2+}$ incorporation into synthetic hexagonal cordierite leads to an elongation of the unit cell in $a$-direction and to a contraction in $c$-direction. In the $\mathrm{Fe}$ end-member the unit cell dimensions of $a=9.8801(6) \AA$ and $c=9.2852(5) \AA$ result in a unit

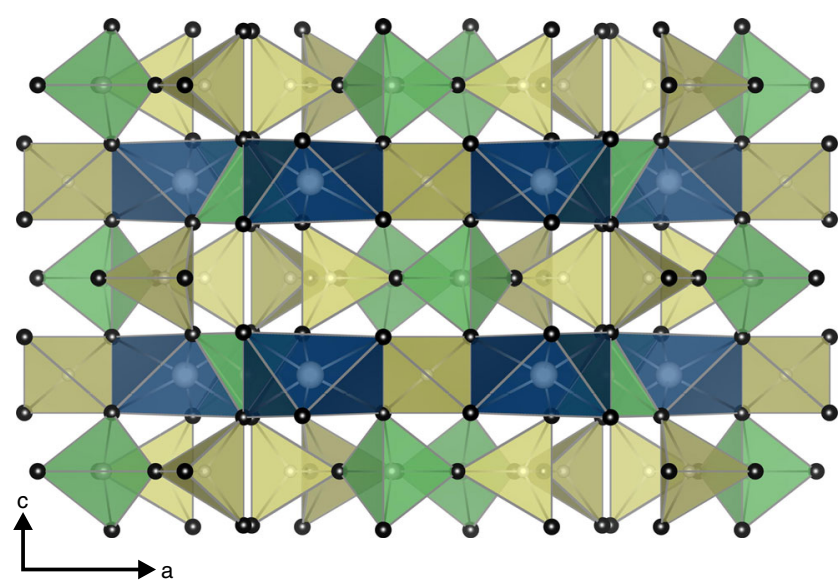

Fig. 3 The crystal structure of orthorhombic Fe-cordierite at room temperature shown along the $b$-axis. The Fe-bearing octahedra are shown in dark blue, the Si-tetrahedra are shown in yellow, the Al-tetrahedra in green

cell volume of 784.95(8) $\AA^{3}$, which is $\sim 1.7 \%$ larger than the cell volume of synthetic $\mathrm{Mg}$-cordierite. The larger $\mathrm{Fe}$ atom in the octahedrally coordinated M-sites leads to an increase of the M-O distances to 2.153(3), resulting in a $\sim 5.5 \%$ volume increase of the octahedra to $12.4 \AA^{3}$. The $\mathrm{T}_{1}-\mathrm{O}$ distances decrease slightly to 1.714(2) $\AA$ and the average $\mathrm{T}_{2}-\mathrm{O}$ distance increases to $1.644(2) \AA$. The volumes of the $\mathrm{T}_{1}$ tetrahedra decrease to $2.481 \AA^{3}$ and the volumes of the $\mathrm{T}_{2}$ tetrahedra increase to $2.308 \AA^{3}$. The distortion parameters are given in Table 1. The O-Fe-O angles in the octahedra scatter extensively with values of $73.66(9)^{\circ}, 84.58(8)^{\circ}$ and $101.05(9)^{\circ}$. This leads to distinct variations in the O-O distances and thus the lengths of the edges of the octahedron. As shown in Fig. 4,

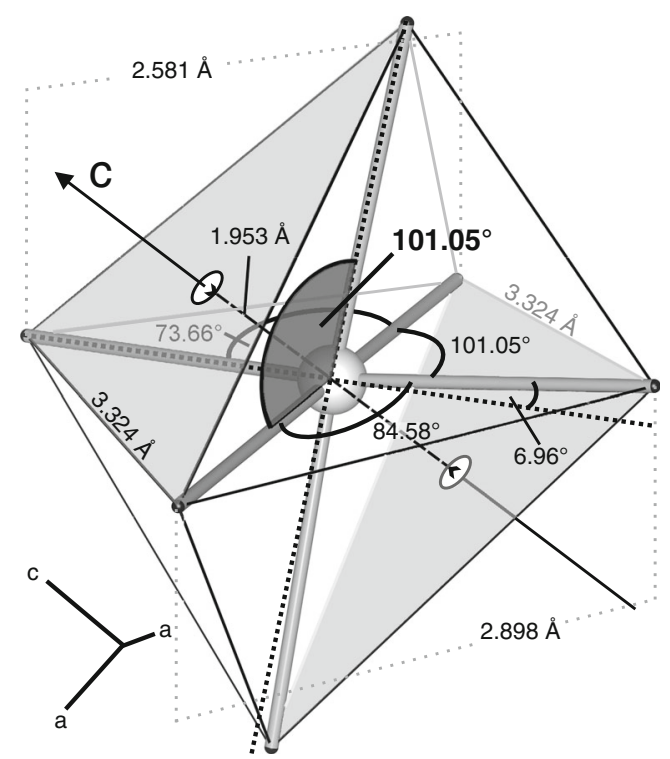

Fig. 4 Selected angles and distances in the distorted octahedron of hexagonal Fe-cordierite. Two octahedral faces perpendicular to the $c$-axis are coloured in light grey. The three angles between the octahedral axes underneath are equal due to the hexagonal symmetry 
the octahedron shows two faces perpendicular to the $c$-axis and angles of $101.05(8)^{\circ}$ between the three octahedron's axes. The octahedral diameter along $c$ is $1.953 \AA$ and thus $0.029 \AA$ smaller when compared to the Mg polymorph. This is assumed as the main reason for the contraction of the $c$ lattice parameter. The adjacent $T_{2}$ tetrahedra show slightly increased (0.0034 $\AA$ ) O-O distances of 2.690(3) $\AA$ parallel to $c$.

The Raman spectrum of the hexagonal Fe-cordierite at ambient conditions (Fig. 2a, b) shows peak shifts towards lower wavenumbers as a consequence of $\mathrm{Fe}$ incorporation when compared to hexagonal Mg-cordierite. Selected peak positions of hexagonal Mg-cordierite from McMillan et al. (1984) are given in parentheses below. In the Fe end-member the peaks at $111 \mathrm{~cm}^{-1}\left(120 \mathrm{~cm}^{-1}\right)$ and $661 \mathrm{~cm}^{-1}\left(672 \mathrm{~cm}^{-1}\right)$ show the highest down-shifts of $9 \mathrm{~cm}^{-1}$ and $11 \mathrm{~cm}^{-1}$ whereas the peak at $372 \mathrm{~cm}^{-1}\left(373 \mathrm{~cm}^{-1}\right)$ shows only a small shift of $1 \mathrm{~cm}^{-1}$. The peaks at $257 \mathrm{~cm}^{-1}\left(256 \mathrm{~cm}^{-1}\right)$ and $568 \mathrm{~cm}^{-1}$ $\left(567 \mathrm{~cm}^{-1}\right)$ show a slightly opposite shift direction of $1 \mathrm{~cm}^{-1}$. Structural similarities between the hexagonal and the orthorhombic cordierite allow peak assignments on the basis of the quantum-mechanical calculations of Kaindl et al. (2011). The peak at $111 \mathrm{~cm}^{-1}$ is mainly the result of bending motions of the $T_{1}$ tetrahedra and the octahedra. Peaks between 230 and $257 \mathrm{~cm}^{-1}$ are mainly related to bending of tetrahedra and octahedra. The peak at $372 \mathrm{~cm}^{-1}$ is related to the bending vibrations of the octahedra and $\mathrm{T}_{2}$ tetrahedra. The region 400 $500 \mathrm{~cm}^{-1}$ is dominated by bending vibrations of the tetrahedra. The intensive peak at $568 \mathrm{~cm}^{-1}$ is related to complex tetrahedral and octahedral stretching vibrations and the peak at $661 \mathrm{~cm}^{-1}$ is a result of the $T_{1}$-bending vibrations. Bands in the range $900-1,200 \mathrm{~cm}^{-1}$ are due to stretching vibrations of the tetrahedra.

Figures $2 \mathrm{~b}$ and $\mathrm{c}$ show the $100-1,250 \mathrm{~cm}^{-1}$ region of the spectrum of hexagonal Fe-cordierite measured at ambient conditions and at $-190{ }^{\circ} \mathrm{C}$ with $633 \mathrm{~nm}$ laser excitation. Peak intensity deviations from Fig. 2a are the result of crystal orientation. The lower the temperature the slightly sharper the peaks become when compared to the spectrum measured at ambient conditions (Fig. 2b, c). The FWHMs of the peak at $257 \mathrm{~cm}^{-1}$ decrease from 17 to 13 , at $370 \mathrm{~cm}^{-1}$ from 14 to 10 and at $567 \mathrm{~cm}^{-1}$ from 25 to 21 . On the other hand the peak positions do not change significantly $\left(<0.5 \mathrm{~cm}^{-1}\right)$, indicating only a low thermal contribution (e.g. Hochella et al. 1979; Haussühl et al. 2011). In Hochella et al. (1979) the temperature-dependent expansion of the axes of orthorhombic cordierite with $X_{\mathrm{Fe}}=$ 0.83 is given with $0.12-0.16 \%$ when heated from 24 to $375^{\circ} \mathrm{C}$. The expansion of hexagonal $\mathrm{Mg}$-bearing cordierite (indialite) in $a$ and $b$ is reported with $<0.1 \%$ at $200{ }^{\circ} \mathrm{C}$ but $c$ decreases slightly. Poon et al. (1990) described the existence of a weak mode on the high-energy side of the $566 \mathrm{~cm}^{-1}$ peak in the spectrum of disordered Mg-cordierite at $253{ }^{\circ} \mathrm{C}$. This peak could not be confirmed for the Fe-end-member in the lowtemperature measurement.

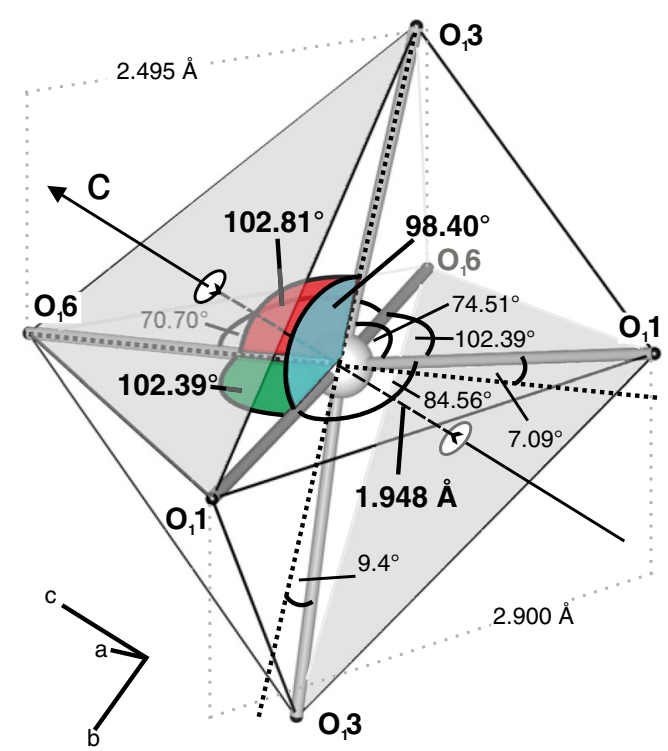

Fig. 5 Selected angles and distances in the distorted octahedron of the orthorhombic Fe-cordierite. Two octahedral faces approximately perpendicular to the $c$-axis are coloured in light grey

Orthorhombic $\mathrm{Fe}^{2+}$-cordierite

Synthetic ordered Fe-cordierite has an orthorhombic unit cell with $a=17.2306(2), b=9.8239$ (1) and $c=9.2892(1) \AA$ and the volume increases as a consequence of $\mathrm{Fe}$ incorporation by $1.5 \%$ to $1572.40(3) \AA^{3}$ when compared with the Mg-endmember. The octahedral volume and distortion increase (Table 1), the O-M-O angles scatter extensively (Fig. 5, Table 7) with values of $70.70(18)^{\circ}, 74.51(16)^{\circ}, 84.56(19)^{\circ}$, $84.93(16)^{\circ}, 98.40(17)^{\circ}, 102.39(15)^{\circ}, 102.81(17)^{\circ}$. The volume increase is related to an expansion in the $a-b$-plane only. A detailed representation of the octahedron is shown in Fig. 5. The average octahedral diameter in direction of the $c$-axis, which commensurates with the average distance of the shaded octahedral faces, is reduced to $1.948 \AA(1.981 \AA, 2.038 \AA$, $1.824 \AA$ ) and the corresponding angles show values of $102.39(15)^{\circ}, 102.81(17)^{\circ}$ and $98.40(17)^{\circ}$, which increase by $1-1.5^{\circ}$ when compared to the Mg-end-member. The reduced octahedral diameter is the main reason for the decrease of the $c$ lattice parameter as a function of $\mathrm{Fe}$ incorporation. Tetrahedral edges in direction of the $c$-axis show a higher O-O-distance variation as a consequence of the more distorted and tilted octahedra. In $\mathrm{T}_{2} 3$ and $\mathrm{T}_{2} 6$ this distance increases to 2.664(10) $\AA$ and 2.820(8) $\AA$, in $T_{2} 1$ it decreases to 2.607(8) $\AA$ thus yielding an average of 2.697(8) $\AA$.

\section{Conclusions}

The octahedral expansion as a function of $\mathrm{Fe}$ incorporation occurs in both synthetic hexagonal as well as orthorhombic cordierite only in the $a-b$-plane. The tetrahedral and octahedral 
interplay results in a notable reduction of the octahedral diameters parallel to $c$, leading to complex changes of polyhedral distortions. The presented site occupancy determinations based on tetrahedral volumes indicate that the $\mathrm{T}_{1}$ tetrahedra in hexagonal Fe-cordierite are significantly enriched in $\mathrm{Al}$ and the $\mathrm{T}_{2}$ tetrahedra contain more Si. Since the O-O distances of the $\mathrm{T}_{2^{-}}$ tetrahedra parallel to $c$ do not change significantly in the hexagonal and decrease only slightly in the orthorhombic polymorph, the overall reduction of the $c$ axis of cordierite as a function of $\mathrm{Fe}$ incorporation is mainly due to changes within the octahedral layer.

From group theoretical analysis 36 Raman active vibrational modes are expected for hexagonal $\mathrm{Fe}$-cordierite of which 21 can be experimentally observed. Although the quantum-mechanical calculations of Kaindl et al. (2011) were done for the orthorhombic polymorph, structural similarities allow the assignment of the observed Raman bands in the spectrum of the hexagonal polymorph to specific vibrational modes involving tetrahedral and octahedral sites. Similar calculations for the hexagonal polymorph are hampered by the $\mathrm{Al} / \mathrm{Si}$ disorder.

Acknowledgments We thank Martina Tribus for her help with the electron microprobe analysis, Jürgen Konzett for his help with the crystal synthesis and Daniel Többens for his help with X-ray powder analysis. Financial support of the Austrian Science Fund (FWF): [P22013-N21 to R.K.] is gratefully acknowledged.

Open Access This article is distributed under the terms of the Creative Commons Attribution License which permits any use, distribution, and reproduction in any medium, provided the original author(s) and the source are credited.

\section{References}

Armbruster T (1985a) Crystal structure refinement, Si, Al-ordering, and twinning in "pseudo-hexagonal" Mg-cordierite. N Jb Mineral Mh 6: 255-267

Armbruster T (1985b) Fe-rich cordierites from acid volcanic rocks, an optical and x-ray single-crystal structure study. Contrib Mineral Petrol 91:180-187

Armbruster T, Bloss FD (1981) Mg-Cordierite: Si/Al ordering, optical properties, and distortion. Contrib Mineral Petrol 77:332-336

Armbruster T, Bloss FD (1982) Orientation and effects of channels $\mathrm{H}_{2} \mathrm{O}$ and $\mathrm{CO}_{2}$ in cordierite. Am Mineral 67:284-291

Balassone G, Franco E, Mattia CA, Puliti R (2004) Indialite in xenolithic rocks from Somma-Vesuvius volcano (Southern Italy): crystal chemistry and petrogenetic features. Am Mineral 89:1-6

Bertoldi C, Proyer A, Garbe-Schönberg D, Behrens H, Dachs E (2004) Comprehensive chemical analyses of natural cordierites: implications for exchange mechanisms. Lithos 78:389-409

Blackburn JF, Salje EKH (1999) Time evolution of twin domains in cordierite: a computer simulation study. Phys Chem Miner 26: 275-296

Boberski C, Schreyer W (1990) Synthesis and water contents of $\mathrm{Fe}^{2+}$ bearing cordierites. Eur J Mineral 2:565-584
Bul'bak TA, Shvedenkov GY (2005) Experimental study on incorporation of C-H-O-N fluid components in Mg-cordierite. Eur J Mineral $17: 829-838$

Cohen JP, Ross FK, Gibbs GV (1977) An X-ray and neutron diffraction study of hydrous low cordierite. Am Mineral 62:67-78

Finger LW, Cox DE, Jephcoat AP (1994) A correction for powder diffraction peak asymmetry due to axial divergence. J Appl Cryst 27:892-900

Geiger CA, Grams M (2003) Cordierite IV: structural heterogeneity and energetics of $\mathrm{Mg}-\mathrm{Fe}$ solid solutions. Contrib Mineral Petrol 145: 752-764

Geiger CA, Rager H, Czank M (2000) Cordierite III: the site occupation and concentration of $\mathrm{Fe}^{3+}$. Contrib Mineral Petrol 140:344-352

Gibbs GV (1966) The polymorphism in cordierite I: the crystal structure of low cordierite. Am Mineral 51:1068-1087

Gunter AE, Skippen GB, Chao GY (1984) Cell dimensions, Mössbauer and infrared-absorption spectra of synthetic cordierite. Can Mineral 22:447-452

Güttler B, Salje E, Putnis A (1989) Structural states of Mg cordierite III: infrared spectroscopy and the nature of the hexagonal-modulated transition. Phys Chem Miner 16:365-373

Haefeker U, Kaindl R, Tropper P (2012) Semi-quantitative determination of the $\mathrm{Fe} / \mathrm{Mg}$ ratio in synthetic cordierite using Raman spectroscopy. Am Mineral 97:1662-1669

Haussühl E, Vinograd VL, Krenzel TF, Schreuer J, Wilson DJ, Ottinger J (2011) High temperature elastic properties of Mg-cordierite: experimental studies and atomistic simulations. Z Kristallogr 226:236-253

Hochella MF, Brown GE, Ross FK, Gibbs GV (1979) High-temperature crystal chemistry of hydrous Mg- and Fe-cordierites. Am Mineral 64:337-351

Horiba (2005) LabSPEC spectral software suite (Version 5.19.17). HORIBA Jobin Yvon, Villeneuve d'Ascq, France

Kaindl R, Tropper P, Deibl I (2006) A semi-quantitative technique for determination of $\mathrm{CO}_{2}$ in cordierite by Raman spectroscopy in thin sections. Eur J Mineral 18:331-335

Kaindl R, Többens D, Haefeker U (2011) Quantum-mechanical calculations of the Raman spectra of Mg- and Fe-cordierite. Am Mineral 96:1568-1574

Kalt A (2000) Cordierite channel volatiles as evidence for dehydration melting: an example from high-temperature metapelites of the Bayerische Wald (Variscan belt, Germany). Eur J Mineral 12:987-998

Khomenko VM, Langer K (2005) Carbon oxides in cordierite channels: determination of $\mathrm{CO}_{2}$ isotopic species and $\mathrm{CO}$ by single crystal IR spectroscopy. Am Mineral 90:1913-1917

Khomenko VM, Langer K, Geiger C (2001) Structural locations of the iron ions in cordierite. Contrib Mineral Petrol 141:381-396

Kolesov BA (2006) Raman spectra of single $\mathrm{H}_{2} \mathrm{O}$ molecules isolated in cavities of crystals. J Struct Chem 47:21-34

Kolesov BA, Geiger CA (2000) Cordierite II: the role of $\mathrm{CO}_{2}$ and $\mathrm{H}_{2} \mathrm{O}$. Am Mineral 85:1265-1274

Langer K, Schreyer W (1969) Infrared and powder X-ray diffraction studies on the polymorphism of cordierite, $\mathrm{Mg}_{2}\left(\mathrm{Al}_{4} \mathrm{Si}_{5} \mathrm{O}_{18}\right)$. Am Mineral 54:1442-1459

Likhacheva AY, Goryainov SV, Krylov AS, Bul'bak TA, Prasad SR (2011) Raman spectroscopy of natural cordierite at high water pressure up to $5 \mathrm{GPa}$. J Raman Spectrosc. doi:10.1002/jrs.3060

Malcherek T, Domeneghetti MC, Tazzoli V, Ottolini L, McCammon C, Carpenter MA (2001) Structural properties of ferromagnesian cordierites. Am Mineral 86:66-79

McMillan P, Putnis A, Carpenter MA (1984) A Raman-spectroscopic study of Al-Si ordering in synthetic magnesium cordierite. Phys Chem Miner 10:256-260

Meagher EP, Gibbs GV (1977) The polymorphism of cordierite II: the crystal structure of indialithe. Can Mineral 15:43-49

Miletich R, Gatta GD, Redhammer GJ, Burchard M, Meyer HP, Weikusat C, Rotiroti N, Glasmacher UA, Trautmann C, Neumann R (2010) 
Structure alterations in microporous (Mg, Fe)2A14Si5O18 crystals induced by energetic heavy-ion irradiation. J Solid State Chem 183: 2372-2381

Mirwald P, Kirchner A (1984) Zum Ordnungs-/Unordnungsverhalten von $\mathrm{Mg}$-Cordierit zwischen $1400{ }^{\circ} \mathrm{C}$ und dem Schmelzpunkt $\left(1463{ }^{\circ} \mathrm{C}\right)$. Fortschr Mineral 62:157-159

Miyashiro A (1957) Cordierite-indialite relations. Am J Sci 255:43-62

Momma K, Izumi F (2011) VESTA 3 for three-dimensional visualization of crystal, volumetric and morphology data. J Appl Cryst 44:1272-1276

Nasdala L, Wildner M, Wirth R, Groschopf N, Pal DC, Möller A (2006) Alpha particle haloes in chlorite and cordierite. Mineral Petrol 86:1-27

Palatinus L, Chapuis G (2007) Superflip - a computer program for the solution of crystal structures by charge flipping in arbitrary dimensions. J Appl Cryst 40:786-790

Petricek V, Dusek M, Palatinus L (2006) Jana 2006. The crystallographic computing system. Institute of Physics, Praha, Czech Republic

Poon WCK, Putnis A, Salje E (1990) Structural states of Mg cordierite: IV. Raman spectroscopy and local order parameter behaviour. J Phys Condens Matter 2:6361-6372

Putnis A (1980) Order-modulated structures and the thermodynamics of cordierite reactions. Nature 287:128-131

Putnis A, Angel RJ (1985) Al, Si ordering in cordierite using "magic angle spinning" NMR. II: models of $\mathrm{Al}, \mathrm{Si}$ order from NMR data. Phys Chem Miner 12:217-222

Putnis A, Bish DL (1983) The mechanism and kinetics of Al, Si ordering in Mg-cordierite. Am Mineral 68:60-65

Putnis A, Fyfe CA, Gobbi GC (1985) Al, Si ordering in cordierite using "magic angle spinning" NMR. I. $\mathrm{Si}^{29}$ spectra of synthetic cordierites. Phys Chem Miner 12:211-216
Putnis A, Salje E, Redfern SAT, Fyfe CA, Strobl H (1987) Structural states of Mg-cordierite I: order parameters from synchrotron X-ray and NMR data. Phys Chem Miner 14:446-454

Rigby MJ, Droop GTR, Bromiley GD (2008) Variations in fluid activity across the Etive thermal aureole, Scotland: evidence from cordierite volatile contents. J Metamorph Geol 26:331-346

Robinson K, Gibbs GV, Ribbe PH (1971) Quadratic elongation: a quantitative measure of distortion in coordination polyhedra. Science 172:467-570

Rodriguez-Carvajal J (2011) FullProf.2k, Version 5.20, Institut LaueLangevin, Grenoble, France

Vry JK, Brown PE, Valley JW (1990) Cordierite volatile content and the role of $\mathrm{CO}_{2}$ in high-grade metamorphism. Am Mineral 75:71-88

Wallace JH, Wenk HR (1980) Structure variation in low cordierites. Am Mineral 65:96-111

Weikusat C, Miletich R, Glasmacher UA, Trautmann C, Neumann R (2010) Heavy-ion irradiation on crystallographically oriented cordierite and the conversion of molecular $\mathrm{CO}_{2}$ to $\mathrm{CO}$ : a Raman spectroscopic study. Phys Chem Miner 37:417-424

Wilson AJC (1995) International tables for crystallography, Vol. C: mathematical, physical and chemical tables. Kluwer Academic Publishers, Dordrecht, Boston, London

Winkler B, Dove MT, Leslie M (1991) Static lattice energy minimization and lattice dynamics calculations on aluminosilicate minerals. Am Mineral 76:313-331

Yakubovich OV, Massa V, Pekov IV, Gavrilenko PG, Chukanov NV (2004) Crystal structure of the Na-, Ca-, Be-cordierite and crystallochemical regularities in the cordierite-sekaninaite series. Crystallogr Rep 49: 953-963 